\title{
Influences of land-use systems and soil depth on some selected soil properties in Akure, Nigeria
}

\author{
Gladys M. Akande ${ }^{1 *}$ and Peace Adeona Adedamola ${ }^{2}$ \\ ${ }^{1}$ Department of Soil and Environmental Management, Kogi State University, Nigeria \\ ${ }^{2}$ Department of Crop, Soil and Pest Management, Federal University of Technology, Akure, Nigeria \\ *Corresponding Author: monisolagladys@gmail.com
}

\begin{abstract}
Land-use changes from natural ecosystems into managed ecosystems resulted in negative effects on soil properties. The main objective of this study was to determine the influence of land-use system and soil depth on some selected soil properties in Akure, Nigeria. The land-use systems studied included oil palm, teak plantation, uncleared forest, cassava land and sugarcane land. Soil samples were collected randomly at four locations in each sample plot at the depths of $0-15 \mathrm{~cm}, 15-30 \mathrm{~cm}$ and $30-75 \mathrm{~cm}$ and the soils thoroughly mixed to obtain a composite sample. Soil samples were analyzed for particle size, $\mathrm{pH}$, organic matter (OM), total nitrogen (TN), Available phosphorus (Av. P), Available potassium (Av. K), Sodium (Na), Calcium (Ca), Magnesium (Mg), Cation exchange capacity (CEC) and Exchangeable acidity (Ex. A). ANOVA (analysis of variance) was used to test the significance of the changes. The results of the study indicated that, the $\mathrm{pH}$ of the land use areas ranges from 4.8 to 6.5 and the soil was sandy. Cassava and sugarcane land resulted in significant decreases in OM, TN, Av. P, Av. K, Ca, Mg, Na and CEC, while the exchangeable acid was high in cassava land, Whereas, the highest values of the same parameters were found under uncleared forest, oil palm and teak plantation land. The results of the study showed that forest clearing and subsequently cultivation and tillage Practices resulted in the decline of the soil quality in cassava and sugarcane land and these changes affect soil properties. Therefore, there should be integrated land management options for different land-use systems to sustain agricultural productivity.
\end{abstract}

Keywords: Soil properties, Land-use system, Forest, Cultivation land.

\section{INTRODUCTION}

Soil as a vital natural resource that performs key environmental, economic, and social functions, as well as the most important resource required for Agricultural production (Khanif, 2010). In the tropical and subtropical regions, soils are well-drained, weathered and low in the availability of major soil nutrients (USDA, 1999). As the interaction between natural and anthropogenic practices on soil persist (Assefa \& Van Keulen, 2009). Soil undergoes a vertical exchange of materials which led to a change in physical and chemical properties from surface soil to sub-soils. The reasons for these changes are as a result of the addition of organic matter from plant growth to the topsoil, rocks weathering and minerals, decomposition of organic matter (Brady \&Weil, 1999).

An increase in population growth and environmental factors lead to the conversion of natural forest and grassland into cultivated farmland has affected the soil properties (Gebreyesus, 2013). Such human-induced land-use changes have led to soil degradation and soil loss by deteriorating the soil's physical and chemical properties and make the ecosystem more delicate and susceptible to land degradation (Karltun et al., 2013).

Land-use changes have remarkable affect the dynamics of soil properties (Ozgoz et al., 2013). For example, landuse changes from natural forests to cultivated land may hinder addition of litter that enhances nutrient content of the soil, as well as accelerate soil degradation, loss of soil organic matter (Biro et al., 2013). Previous researchers as stated that, land-use system affects the productivity of soil, as well as changes in soil properties such as contents of available of macro and micronutrient, organic matter and CEC (Aluko et al., 2000; Barua \& Haque, 2013; Saha \& Kukal, 2015). According to Majaliwa et al. (2010), Land-use change affects the distribution and supply of soil nutrients by altering soil properties and influencing the rooting zone by biological transformations.

The fate of the soil properties, soil quality has been determined by land-use system (Zhao et al., 2013). Due to soil degradation and soil losses which have led to deteriorating of soil physical and chemical properties, through the conversion of natural forest to cultivated farmland. This further suggests the need for determination of soil properties. To this end, little or no work has been done on the effects of land use and soil depth on soil properties in Akure, Nigeria. In realization of the above fact, coupled with the ever-increasing demand for rapid farm production in Nigeria and Akure in particular, there is a need to determined soil properties as well as the Influences of land-use systems and soil depth on some selected soil properties in Akure, Nigeria. 


\section{MATERIAL AND METHOD}

\section{Site description}

The present study was undertaken at the Teaching and Research Farm of the Federal University of Technology, Akure $\left(7^{\circ} 18^{\prime} \mathrm{N}, 5^{\circ} 7^{\prime} \mathrm{E}\right)$. The mean annual precipitation (occurs mainly from March to October) and the dry season of four months (November to February), with a mean annual precipitation of 1000 to $1250 \mathrm{~mm}$ and a mean annual temperature of about $27^{\circ} \mathrm{C}$ with an elevation ranged from 255 to 381 meters above sea level

\section{Land-use}

The land-use areas were oil palm, teak plantation, unclear forest, cassava and sugar. Previous research had revealed that shifting cultivation and some common crops planted include Cassava (Manihot esculenta Crantz), cocoyam (Colocasia esculenta (L.) Schott), melon (Cucumis melo L.) and maize (Zea mays L.). Also, information from the indigenes showed that the forests have never been cleared, cultivated or burnt for about 100 years (Fasinmirin \& Oguntuase, 2008).

\section{Soil sampling and preparation}

Soil samples were collected at the depths of 0-15 cm, $15-30 \mathrm{~cm}$ and $30-75 \mathrm{~cm}$ at four locations in each sample plot and the soils thoroughly mixed to obtain a composite sample. All soil samples were air-dried, ground and passed through $2 \mathrm{~mm}$ sieve and the physicochemical analyses of the soil samples were conducted at the Soil Laboratory of the Crop, Soil and Pest management of the federal university of Technology, Akure.

\section{Laboratory analysis}

Soil samples were analysed for physical and chemical properties, following the laboratory procedures described by Carter (1993). Soil particle size (soil texture) was done by the hydrometer method. Soil pH and electrical conductivity (EC) were measured using $\mathrm{pH}$ meter and EC meter respectively. Organic matter (OM) content of the soil was determined using Walkley-Black method. Soil Total Nitrogen (TN) was analyzed by Kjeldahal method. The available Phosphorus (Av. P) contents was analyzed using the Bray p-1 method, also extractable $\mathrm{K}^{+}$and $\mathrm{Na}^{+}$was measured by flame Photometer. The exchangeable basic cations $\left(\mathrm{K}^{+}, \mathrm{Ca}^{2+}, \mathrm{Mg}^{2+}\right.$, and $\left.\mathrm{Na}^{+}\right)$were extracted with $1 \mathrm{M}$ ammonium acetate at $\mathrm{pH}=7.0$. The $\mathrm{CEC}$ of the soil was determined from ammonium acetate saturated sample. The excess

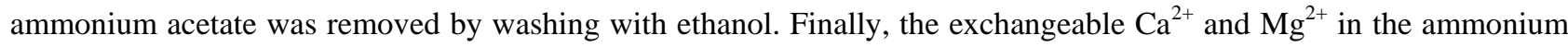
acetate leachate were measured by atomic absorption spectrophotometry (AAS).

\section{RESULTS}

Influences of land-use types and soil depths on soil particles size are shown in table 1 . The results show that, the dominant soil texture in this project area is sand. Many of the soil samples belong to sandy loam category but there are also few cases of sandy clayey and loam.

\begin{tabular}{llllll}
\multicolumn{6}{l}{ Table 1. Influence of land-use types and soil depths on soil particles size. } \\
\hline Land use & Depth $(\mathbf{c m})$ & Sand $(\%)$ & Silt $(\%)$ & Clay $(\%)$ & Textural class \\
\hline Oil palm & $0-15$ & $62 \mathrm{a}$ & $10 \mathrm{~b}$ & $22 \mathrm{~h}$ & Sandy loam \\
& $15-30$ & $54 \mathrm{abcde}$ & $14 \mathrm{~b}$ & $32 \mathrm{def}$ & Sandy loam \\
& $30-75$ & $48 \mathrm{abcdefg}$ & $11 \mathrm{~b}$ & $40 \mathrm{ab}$ & Sandy clay loam \\
Teak & $0-15$ & $60 \mathrm{ab}$ & $18 \mathrm{ab}$ & $21 \mathrm{~b}$ & Sandy loam \\
& $15-30$ & $52 \mathrm{bcdefg}$ & $19 \mathrm{ab}$ & $29 \mathrm{efg}$ & Sandy loam \\
& $30-75$ & $46 \mathrm{efg}$ & $23 \mathrm{~b}$ & $42 \mathrm{a}$ & Sandy clay loam \\
Uncleared & $0-15$ & $54 \mathrm{abcdef}$ & $15 \mathrm{ab}$ & $29 \mathrm{efg}$ & Sandy loam \\
forest & $15-30$ & $50 \mathrm{abcdefg}$ & $17 \mathrm{ab}$ & $33 \mathrm{cde}$ & Sandy loam \\
& $30-75$ & $45 \mathrm{efg}$ & $20 \mathrm{ab}$ & $35 \mathrm{~cd}$ & Sandy clay loam \\
Cassava & $0-15$ & $59 \mathrm{abc}$ & $15 \mathrm{~b}$ & $25 \mathrm{gh}$ & Sandy loam \\
& $15-30$ & $46 \mathrm{fg}$ & $24 \mathrm{a}$ & $32 \mathrm{def}$ & Sandy loam \\
& $30-75$ & $44 \mathrm{fg}$ & $18 \mathrm{ab}$ & $36 \mathrm{bcd}$ & Sandy clay loam \\
Sugarcane & $0-15$ & $58 \mathrm{abcd}$ & $15 \mathrm{~b}$ & $27 \mathrm{fg}$ & Sandy loam \\
& $15-30$ & $52 \mathrm{bcdefg}$ & $17 \mathrm{a}$ & $31 \mathrm{def}$ & Sandy loam \\
& $30-75$ & $42 \mathrm{~g}$ & $20 \mathrm{ab}$ & $38 \mathrm{abc}$ & Sandy clay loam \\
\hline
\end{tabular}

Note: Mean followed by the same letter in each column are not significantly different from each other by Duncan's multiple Range Test (DMRT) at 5\% level of probability.

Influences of land-use types and soil depths on soil chemical properties were shown in table 2. $\mathrm{pH}$ varies from 4.8 to 6.5 with the highest valve recorded under uncleared forest at the depth of $0-15 \mathrm{~cm}$ and the lowest valve were recorded in sugarcane land at the depths of $30-75 \mathrm{~cm}$. $\mathrm{pH}$ of the study area indicates that most of the area ranges from acidic to slightly acidic. 
Organic matter contents was high in oil palm land with the valve of $6.13 \%$ at the depth of $0-15 \mathrm{~cm}$ and low in cassava land with the valve of $0.10 \%$ at the depths of $30-75 \mathrm{~cm}$, respectively. Total $\mathrm{N}$ (nitrogen) content was significantly high at the depths of $0-13 \mathrm{~cm}$ in uncleared forest land with $0.49 \%$ and lowest value was observed at the depths $0-15 \mathrm{~cm}$ in sugarcane land with $0.13 \%$. The available phosphorus was significantly high at the depths of 30-75 $\mathrm{cm}$ layer of teak land with $2.85 \mathrm{mg} \mathrm{kg}^{-1}$ value and the lowest value was observed at the depths $0-15 \mathrm{~cm}$ layer of cassava land, respectively with $0.45 \mathrm{mg} \mathrm{kg}^{-1}$ value.

Table 2. Influence of land-use types and soil depths on soil $\mathrm{pH}, \mathrm{OM}, \mathrm{N}, \mathrm{Av}$. P.

\begin{tabular}{llllll}
\hline Land use & Depth $(\mathbf{c m})$ & $\mathbf{p H}\left(\mathbf{H}_{\mathbf{2}} \mathbf{0}\right)$ & $\mathbf{O M}(\boldsymbol{\%})$ & $\mathbf{N}(\boldsymbol{\%})$ & $\mathbf{A v .} \mathbf{P}\left(\mathbf{m g ~ k g}^{-1}\right)$ \\
\hline Oil palm & $0-15$ & $6.1 \mathrm{c}$ & $6.13 \mathrm{a}$ & $0.37 \mathrm{bc}$ & $1.45 \mathrm{k}$ \\
& $15-30$ & $5.0 \mathrm{c}$ & $5.03 \mathrm{~b}$ & $0.40 \mathrm{ab}$ & $0.54 \mathrm{k}$ \\
\multirow{4}{*}{ Teak } & $30-75$ & $4.8 \mathrm{a}$ & $4.87 \mathrm{~b}$ & $0.47 \mathrm{a}$ & $1.84 \mathrm{ef}$ \\
& $0-15$ & $6.0 \mathrm{c}$ & $1.07 \mathrm{c}$ & $0.30 \mathrm{~cd}$ & $0.88 \mathrm{j}$ \\
& $15-30$ & $4.9 \mathrm{c}$ & $1.30 \mathrm{c}$ & $0.27 \mathrm{~d}$ & $2.35 \mathrm{~b}$ \\
Uncleare & $30-75$ & $4.7 \mathrm{ab}$ & $1.07 \mathrm{c}$ & $0.30 \mathrm{ed}$ & $2.85 \mathrm{a}$ \\
forest & $0-15$ & $6.5 \mathrm{a}$ & $1.09 \mathrm{~d}$ & $0.49 \mathrm{bc}$ & $1.98 \mathrm{de}$ \\
& $15-30$ & $6.3 \mathrm{c}$ & $1.35 \mathrm{e}$ & $0.23 \mathrm{~d}$ & $2.14 \mathrm{~cd}$ \\
Cassava & $30-75$ & $5.4 \mathrm{a}$ & $1.42 \mathrm{e}$ & $0.30 \mathrm{~cd}$ & $1.76 \mathrm{f}$ \\
& $0-15$ & $6.2 \mathrm{c}$ & $0.35 \mathrm{ef}$ & $0.30 \mathrm{~cd}$ & $0.45 \mathrm{~g}$ \\
& $15-30$ & $5.2 \mathrm{c}$ & $0.83 \mathrm{f}$ & $0.37 \mathrm{ab}$ & $1.88 \mathrm{ef}$ \\
Sugarcane & $30-75$ & $5.1 \mathrm{a}$ & $0.10 \mathrm{f}$ & $0.43 \mathrm{ab}$ & $1.10 \mathrm{i}$ \\
& $0-15$ & $5.9 \mathrm{c}$ & $0.62 \mathrm{de}$ & $0.13 \mathrm{ab}$ & $1.34 \mathrm{~g}$ \\
& $15-30$ & $4.9 \mathrm{ab}$ & $0.59 \mathrm{de}$ & $0.48 \mathrm{a}$ & $2.33 \mathrm{bc}$ \\
& $30-75$ & $4.0 \mathrm{c}$ & $0.49 \mathrm{de}$ & $0.30 \mathrm{~cd}$ & $1.25 \mathrm{fg}$ \\
\hline
\end{tabular}

Note: Mean followed by the same letter in each column are not significantly different from each other by Duncan's multiple Range Test (DMRT) at 5\% level of probability.

The influence of land-use types and soil depths on soil exchangeable cations and exchangeable acidity was shown in table 3.The mean exchangeable $\mathrm{K}$ was significantly high at the depth of $0-15 \mathrm{~cm}$ of teak plantation with $0.93 \mathrm{cmol} \mathrm{kg}^{-1}$ and the lowest value was obtained at depths of $15-30 \mathrm{~cm}$ of cassava with $0.10 \mathrm{cmol} \mathrm{kg}^{-1}$. Exchangeable calcium was significantly high with $5.80 \mathrm{cmol} \mathrm{kg}^{-1}$ value, was recorded at the depths of $0-15 \mathrm{~cm}$ layer of the teak land, and the lowest value with $3.19 \mathrm{cmol} \mathrm{kg}^{-1}$ was obtained at the depths of $0-15 \mathrm{~cm}$ of the sugarcane land. The exchangeable Magnesium was high at the depths of $0-15 \mathrm{~cm}$ of uncleared forest land with $3.27 \mathrm{cmol} \mathrm{kg}^{-1}$ and the lowest at the depths of $0-15 \mathrm{~cm}$ of sugarcane land with $0.25 \mathrm{cmol} \mathrm{kg}^{-1}$.

Table 3. Influence of land-use types and soil depths on soil exchangeable cations and exchangeable acidity.

\begin{tabular}{llllllll}
\hline Land use & Depth $(\mathbf{c m})$ & $\mathbf{K}$ & $\mathbf{C a}$ & $\mathbf{M g}$ & $\mathbf{N a}$ & $\mathbf{C E C}$ & $\mathbf{E x} . \mathbf{A}\left(\mathbf{c m o l ~ k g}^{-\mathbf{1}}\right)$ \\
\hline Oil palm & $0-15$ & $0.28 \mathrm{~g}$ & $3.36 \mathrm{e}$ & $2.35 \mathrm{~b}$ & $0.08 \mathrm{gh}$ & $9.99 \mathrm{~g}$ & $0.49 \mathrm{a}$ \\
& $15-30$ & $0.36 \mathrm{gh}$ & $4.20 \mathrm{c}$ & $0.33 \mathrm{i}$ & $0.15 \mathrm{fg}$ & $11.76 \mathrm{~b}$ & $0.48 \mathrm{de}$ \\
& $30-75$ & $0.34 \mathrm{~h}$ & $5.10 \mathrm{~b}$ & $0.40 \mathrm{i}$ & $0.12 \mathrm{fg}$ & $10.28 \mathrm{a}$ & $0.47 \mathrm{c}$ \\
Teak & $0-15$ & $0.93 \mathrm{e}$ & $5.80 \mathrm{a}$ & $1.73 \mathrm{~d}$ & $0.45 \mathrm{~d}$ & $14.28 \mathrm{de}$ & $0.44 \mathrm{de}$ \\
& $15-30$ & $0.73 \mathrm{~d}$ & $5.18 \mathrm{~b}$ & $2.14 \mathrm{c}$ & $0.14 \mathrm{e}$ & $9.15 \mathrm{~cd}$ & $0.42 \mathrm{~b}$ \\
& $30-75$ & $0.57 \mathrm{~d}$ & $4.54 \mathrm{c}$ & $1.76 \mathrm{~d}$ & $0.13 \mathrm{ef}$ & $10.34 \mathrm{~cd}$ & $0.40 \mathrm{c}$ \\
Uncleare & $0-15$ & $0.13 \mathrm{f}$ & $4.28 \mathrm{c}$ & $3.25 \mathrm{fg}$ & $0.13 \mathrm{ef}$ & $7.81 \mathrm{~g} \mathrm{a}$ & $0.41 \mathrm{~g}$ \\
forest & $15-30$ & $0.45 \mathrm{~b}$ & $4.54 \mathrm{c}$ & $1.02 \mathrm{fg}$ & $0.22 \mathrm{~b}$ & $8.81 \mathrm{~g}$ & $0.40 \mathrm{~d}$ \\
& $30-75$ & $0.55 \mathrm{a}$ & $5.50 \mathrm{~b}$ & $0.90 \mathrm{gh}$ & $0.93 \mathrm{~g}$ & $9.48 \mathrm{cde}$ & $0.27 \mathrm{c}$ \\
Cassava & $0-15$ & $0.88 \mathrm{gh}$ & $3.36 \mathrm{e}$ & $2.27 \mathrm{bc}$ & $0.55 \mathrm{a}$ & $6.80 \mathrm{~g}$ & $1.27 \mathrm{~g}$ \\
& $15-30$ & $0.10 \mathrm{f}$ & $4.08 \mathrm{~cd}$ & $1.17 \mathrm{f}$ & $0.33 \mathrm{c}$ & $9.66 \mathrm{~cd}$ & $0.93 \mathrm{fg}$ \\
& $30-75$ & $0.40 \mathrm{c}$ & $4.34 \mathrm{c}$ & $1.42 \mathrm{e}$ & $0.10 \mathrm{~g}$ & $11.73 \mathrm{~b}$ & $0.49 \mathrm{de}$ \\
Sugarcane & $0-15$ & $0.11 \mathrm{f}$ & $3.19 \mathrm{e}$ & $0.25 \mathrm{a}$ & $0.13 \mathrm{ef}$ & $8.58 \mathrm{f}$ & $0.51 \mathrm{de}$ \\
& $15-30$ & $0.90 \mathrm{~g}$ & $4.38 \mathrm{c}$ & $1.73 \mathrm{~d}$ & $0.07 \mathrm{~h}$ & $10.30 \mathrm{~cd}$ & $0.48 \mathrm{fg}$ \\
& $30-75$ & $0.77 \mathrm{gh}$ & $3.61 \mathrm{de}$ & $1.43 \mathrm{e}$ & $0.05 \mathrm{~h}$ & $7.48 \mathrm{f}$ & $0.44 \mathrm{~g}$ \\
\hline
\end{tabular}

Note: Mean followed by the same letter in each column are not significantly different from each other by Duncan's multiple Range Test (DMRT) at 5\% level of probability.

Exchangeable sodium $(\mathrm{Na})$ contents were significantly high at the depths of $30-75 \mathrm{~cm}$ of uncleared forest land with $0.93 \mathrm{cmol} \mathrm{kg}^{-1}$ and low at depths of 30-70 $\mathrm{cm}$ of the sugarcane land with value $0.05 \mathrm{cmol} \mathrm{kg}^{-1}$ respectively. The CEC content was significantly high at the depths of $0-15 \mathrm{~cm}$ of teak land with the value $14.28 \mathrm{cmol} \mathrm{kg}^{-1}$ recorded, whereas the lowest $6.80 \mathrm{cmol} \mathrm{kg}^{-1}$ was observed at the depths of $0-15 \mathrm{~cm}$ of the cassava land. The exchangeable acidity was significantly high at the soil depths of $0-15 \mathrm{~cm}$ in cassava land with $1.27 \mathrm{cmol} \mathrm{kg}^{-1}$ value whereas, the lowest value of $0.27 \mathrm{cmol} \mathrm{kg}^{-1}$ was observed at depths of $30-75 \mathrm{~cm}$ the uncleared forest. 


\section{DISCUSSION}

\section{Influence of land-use and soil depths on soil physical properties}

From the results in table 1, it was observed that, the land-use soils are more of sand fractions. The texture of the soils was generally sand loamy. The high percentage of sand observed in all the land use areas might be attributed to the geology of the area. This study was in agreement with Akamigbo \& Ukaegbu (2003) who revealed the geology of the study area to be coastal plain sands, which had led sandy soils over a wide expanse of land. However, there was a clear relationship between soil depths and the land use type in the study area. The sand contents of the soil decreased with an increase in soil depth whereas the clay percentage increased with an increase in soil depth, which was a sign of clay translocation. This result was in agreement with the previous research conducted by (Voundi et al., 2002).

From the table 1 , the surface layer $(0-15 \mathrm{~cm})$ which produced the highest substantial quantity of sand in all the land use system and the least quantity of silt respectively, could be due to the surface soil being exposed to the direct impact of weather elements and management practices, which might have contributed indirectly to the changes in particle size distribution particularly in the subsoil layers as a result of removal of soil by sheet and rill erosions, and mixing up of the surface and the subsurface layers during continuous tillage activities. This result was in agreement with Yifru \& Taye (2011).

\section{Influence of land-use and soil depths on soil chemical properties Soil $\mathrm{pH}\left(1: 2 \mathrm{H}_{2} \mathrm{O}\right)$}

The lowest value of $\mathrm{pH}$ under the sugar cane land may be due to two major reasons. The first was the depletion of basic cations in crop harvest and drainage to streams in runoff generated from accelerated erosions. Secondly, it might be due to its highest microbial oxidation that produced organic acids, which provided hydrogen ions to the soil solution and reduced soil $\mathrm{pH}$ content. Generally, the $\mathrm{pH}$ values observed in the study area were within the range of strongly acidic to slightly acidic as indicated by (Foth et al., 1997). In general, pH values decreased with increasing soil depth (Table 2). The reason could be the reduction of $\mathrm{Ca}$ and $\mathrm{Mg}$ ions along soil depth which reduced soil $\mathrm{pH}$ from top to down the soil layers

\section{Soil organic matter}

Table 3, which showed that, oil palm had the highest organic matter contents, was as a result of the more canopy formed by oil palm and species age of the oil palm could have a great influence on soil organic matter contents, the study was in agreements with (Bizuhoraho et al., 2018). The decline in soil organic matter contents in the cassava land might be as a result of a reflection of continuous cultivation and pedogenic processes. This general truth was assured by Onyekwere et al., (2003).

\section{Soil total Nitrogen}

Higher total nitrogen (TN) content that was observed in uncleared forest land, maybe due to an abundance of legume trees and Azotobacter algae (able to fix atmospheric nitrogen), decaying plant and animal matter, and nitrogen compounds produced by thunderstorms (Hall, 2008). The results were in line with the findings of Duguma et al. (2010) who found higher $\mathrm{N}$ in woodlot and pasture land compared to agricultural lands. The low total nitrogen that was observed in sugar cane land might be as results of more tillage and no addition of fertilizer that replaced the removed TN by continuous tillage. The result of this study agrees with several studies conducted by Yifru \& Taye (2011).

\section{Available phosphorus}

The highest available Phosphorus was recorded in teak land, at the depth of 30-75 cm and cassava land had significantly lower available phosphors. This could happen, due to high erosion, low organic and inorganic fertilizer application and crop residue removal in the cassava land. The finding was in agreements with previous researchers (Yitbarek et al., 2013; Bezabih et al., 2014).

\section{Basic exchangeable cations}

The higher content of $\mathrm{Ca}^{+}$was recorded in teak land and lowest in sugarcane land. The lowest value of $\mathrm{Ca}^{+}$obtained on the sugarcane land could be also be related to influence of intensity of cultivation and abundant crop harvest with little or no use of input as reported by (Singh et al., 1995; He et al., 1999). The higher content of Exchangeable Mg in uncleared forest land at the surface soil is probably due to forest litter and dead plant accumulation and it may due to the association of biological accumulation with biological activity and accumulation from plant as reported by (Korkanc et al., 2008).

The higher exchangeable $\mathrm{K}^{+}$in the teak land could be due to the presence of a tree which pumps the cation through their deeper roots. While the lower $\mathrm{K}^{+}$in the cassava land may due to a large $\mathrm{K}^{+}$removal by the soil erosion, continuous cultivation and continuous losses in the harvested parts of the plants from cassava land. The previous finding had also considered these factors and the application of acid-forming fertilizers as major factors affecting the distribution of $\mathrm{K}^{+}$ 
in soil systems mainly enhancing its depletion especially in tropical soils (Wakene et al., 2001; Hargreaves et al., 2015).

Cation Exchange Capacity (CEC)

The highest and the lowest values of CEC which were observed under the teak land and cassava land could be addressed to the strong association of CEC with soil organic matter. The degradation of organic matter had left the soil of cassava land with low CEC and soil CEC is importance for soil fertility maintenance as it influences the nutrients quantity available to plant at exchange site. This study is in agreement with (Baker et al., 1997) because of the presence of high contents organic matter on the teak land as well as on oil palm land Thus, CEC of the soil are influenced by OM of the soil (Adeboye et al., 2011).

\section{Exchangeable acidity}

The higher value and the lowest value of exchangeable acidity were recorded under the cassava land and the uncleared forest lands, respectively (Table 3). It might be as a result of deforestation, intensive cultivation and application of inorganic fertilizers leads to the higher exchangeable acidity content under the cassava land. The results of this study were in agreement with (Wakene et al., 2001), who reported that inorganic fertilizer application was the root cause of soil acidity in most soil.

\section{CONCLUSION}

From the study, it was possible to conclude that soil properties significantly vary among land-use systems. The studied sites especially cassava land and sugarcane land seem to have low TN, OM, available P and CEC. Whereas, the highest values of the same parameters were found under uncleared forest, oil palm and teak plantation land, It was apparent that shift in land-use systems from natural forest to other land-use systems had a detrimental effect on soil properties. Due to an increase in population growth and environmental factors lead to the conversion of natural forest into cultivated farmland has affect the soil properties. Therefore, it is recommended that different integrated land management should be options for different land-use systems to sustain agricultural productivity in cultivated lands of the study area.

\section{ACKNOWLEDEGMENTS}

We the Authors also like to thank the Department of Crop, Soil and Pest management of Federal university of Technology, Akure, Nigeria for their support in creating laboratory facilities, which helped in carrying out this research work.

\section{REFERENCE}

Adeboye M., Bala A., Osunde A., Uzoma A., Odofin A. \& Lawal B. (2011). Assessment of soil quality using soil organic carbon and total nitrogen and microbial properties in tropical agroecosystems. Journal of Agricultural Science, 2: 34-40.

Akamigbo F.O.R \& Ukaegbu C.E. (2003). Influence of Parent Materials on the Soil of South Eastern Nigeria. Agricultural Journal, 4: 81-86.

Aluko A. \& Fagbenro J. (2012). The role of tree species and land use systems in organic matter and nutrient availability indegraded Ultisol of Onne, Southeastern Nigeria". Mental Sciences 2(3): 57-71.

Assefa A. \& Van Keulen H. (2009). Modeling soil nutrient dynamics underalternative farm management practices in the Northern Highlandsof Ethiopia. Soil \& Tillage Research, 103: 203-215.

Baker M.R., Nys C. \& Picard J.F. (1997). The effect of liming and gypsum applications on a sessile oak (Quercus petraea) stand at Larcroix-Scaille (French Ardennes). I. Site Characteristics, soil chemistry and aerial biomass. Plant Soil, 150: 99-108.

Barua S.K. \& Haque S.M.S. (2013). Soil characteristics and carbon sequestration potentials of vegetations in degraded hills of Chittagong, Bangladesh. Land Degradation \& Devevelopment, 24: 63-71,

Bezabih B., Regassa A. \& Lemenih M. (2014). Soil Fertility Status as Affected by Different Land Use Types and Topographic Positions: A Case of Delta Sub-Watershed, Southwestern Ethiopia. Journal of Biology, Agriculture and Healthcare, 4(27): 91106

Biro K., Pradhan B., Muchroithner M. \& Makeschin F. (2013). Land use/land cover change analysis and its impact on soil properties in the northern part of Gadarif region, Sudan. Land Degradation \& Devevelopment, 24: 90-102.

Bizuhoraho A., Kayiranga N., Manirakiza \& Mourad K.A. (2018). The effect of land use systems on soil properties; a case study from Rwanda. Sustainable Agriculture Research, 7(2): 30-40.

Brady N.C. \& Weil R.R. (1999). The Nature and Properties of Soils, $12^{\text {th }}$ Ed. Prentice Hall, New Jersey.

Carter M.R. (Ed.) (1993). Soil Sampling and Methods of Analysis. Canadian Soil Science Society. Lewis Publishers, Boca Raton, Florida, $823 \mathrm{p}$.

Duguma L.A., Hager H. \& Sieghardt M. (2010). Effects of land use types on soil chemical properties in smallholder farmers of central highland Ethiopia. Ekológia (Bratislava), 29(1): 114.

Fasinmirin J.T. \& Oguntuase A.M. (2008). Soil moisture distribution pattern in Amaranthus cruentus field under drip irrigation system. African Journal of Agricultural Research, 3: 486-493. 
Foth H.D. \& Ellis B.G. (1997). Soil fertility, $2^{\text {nd }}$ Ed. Lewis CRC Press LLC., USA, 290 p.

Gebreyesus B.T. (2013). Soil quality indicators response to land use and soil management 20 systems in Northern Ethiopia's catchment. Land Degradation \& Development, 27: 438-448.

Hall R. (2008). Soil Essentials: Managing your Farm's Primary Asset. Land links Press, Collingwood.

Hargreaves P. (2015). Soil Texture and pH Effects on Potassium and Phosphorus Availability. The potash Development Association, London, UK.

He Z.L., Alva A.K., Calvert D.V., Li Y.C. \& Banks D.J. (1999). Effects of N fertilization of grapefruit trees on soil acidification and nutrient availability in Riviera Fine sand. Plant and Soil, 206: 11-19.

Karltun E., Lemenih M. \& Tolera M. (2013). Comparing farmers' perception of soil fertility change with soil properties and crop performance in Beseku, Ethiopia. Land Degradation \& Development, 24: 228-235.

Khanif Y.M. (2010). Improvement of Soil Carrying Capacity for Better Living Department of Land Management. Faculty of Agriculture University Putra Malaysia, 43400, Serdang Selangor Malaysia.

Korkanc S.Y., Ozyuvaci N. \& Hizal A. (2008). Impacts of land use conversion on soil properties and soil erodiblity. Journal of Environmental Biology, 29: 363-370.

Majaliwa G., Twongyirwe R., Nyenje R., Oluka M., Ongom B., Sirike J., Mfitumukiza D., Azanga E., Natumanya V., Mwerera R. \& Barasa B. (2010). The Effect of Land Cover Change on Soil Properties around Kibale National Park in South Western Uganda. Applied and Environmental Soil Science, 1(10): 1-7.

Onyekwere I.N., Ano A.O. \& Bala, B.O. (2003). Assessment of Exchangeable Acidity Status and Management of Wet Land Soil of Cross River State). Nigeria Agricultural Production and Environment, 3(I): 207-209.

Ozgoz E., Gunal H., Acir N., Gokmen F.M., Birol M. \& Budak M. (2013). Soil quality and spatial variability assessment of land use effects in a typic Haplustoll. Land Degradation \& Development, 24: 277-286.

Saha D. \& Kukal Z.P. (2015). Soil structural stability and water retention characteristics under different land uses of degraded 5 lower Himalayas of North-West India. Land Degradation \& Development, 26: 263-271.

Singh G., Singh N.T. \& Dagar J.C. (1995). Alternate land management systems for sustainable development of salt affected soils. In: Agroforestry Systems for Degraded Lands, Vol. 1. Science Publishers, USA, p. 104-110.

USDA (1999) Soil Taxonomy: a Basic System of Soil Classification for Making and Interpreting Soil Surveys, $2^{\text {nd }}$ Ed. Agriculture Handbook Number 436, United States Department of Agriculture, Natural Resources Conservation Section, Washington, DC.

Voundi Nkana J.C. \& Tonye J. (2002). Assessment of certain soil properties related to different land-use systems in the Kaya watershed of the humid forest zone of Cameroon. Land Degradation and Development, 14(1): 57-67.

Wakene N. (2001). Assessment of important physicochemical properties of Dystric Udalf (Dystric Nitosols) under different management systems in Bako area, western Ethiopia, (M.Sc. Thesis). School of Graduate Studies, Alemaya University, Ethiopia, $93 \mathrm{p}$.

Yifru A. \& Taye B. (2011). Effects of land use on soil organic carbon and nitrogen in soils of Bale, South-eastern Ethiopia. Tropical and Subtropical Agroecosystems, 14: 229-235.

Yitbarek T., Heluf G., Kibebew K. \& Shelem B. (2013). Impacts of land use on selected physicochemical properties of soils of Abobo area, western Ethiopia. Agriculture, Forestry and Fisheries, 2(5):177-183.

Zhao G., Mu X., Wen Z., Wang F. \& Gao P. (2013). Soil erosion, conservation, and Eco environment changes in the Loess Plateau of China. Land Degradation \& Development, 24: 499-510. 